Article

\title{
Massive Transformation in Titanium-Silver Alloys and Its Effect on Their Mechanical Properties and Corrosion Behavior
}

\author{
Mi-Kyung Han ${ }^{1}$, Moon-Jin Hwang ${ }^{1}$, Dae-Hee Won ${ }^{2}$, Yang-Soo Kim ${ }^{3}$, Ho-Jun Song ${ }^{1}$ and \\ Yeong-Joon Park ${ }^{1, *}$
}

1 Department of Dental Materials and Medical Research Center for Biomineralization Disorders, School of Dentistry, Chonnam National University, Gwangju 500-757, Korea;

E-Mails: mikihan@jun.ac.kr (M.-K.H.); mjhwang@jnu.ac.kr (M.-J.H.); songhj@jnu.ac.kr (H.-J.S.)

2 Industry-Academic Cooperation Foundation, Wonkwang University, Jeonbuk 570-749, Korea;

E-Mail: oneday@wku.ac.kr

3 Sunchon Center, Korea Basic Science Institute, Sunchon 540-950, Korea;

E-Mail: kimyangsoo@kbsi.re.kr

* Author to whom correspondence should be addressed; E-Mail: yjpark@jnu.ac.kr;

Tel.: +82-62-530-4871; Fax: +82-62-530-4875.

Received: 20 June 2014; in revised form: 9 August 2014 / Accepted: 25 August 2014 /

Published: 29 August 2014

\begin{abstract}
In order to investigate the relationship between phase/microstructure and various properties of $\mathrm{Ti}-x \mathrm{Ag}$ alloys, a series of $\mathrm{Ti}-x \mathrm{Ag}$ alloys with $\mathrm{Ag}$ contents ranging from 5 to $20 \mathrm{wt} \%$ were prepared. The microstructures were characterized using X-ray diffractometry (XRD), optical microscopy (OM), scanning electron microscopy (SEM) and transmission electron microscopy (TEM). All of the $\mathrm{Ti}-x \mathrm{Ag}$ alloys showed a massive transformation from the $\beta$-Ti to $\alpha_{m}$ phase, which has a different crystal structure from that of the matrix phase, but it has the same composition as the matrix $\alpha$-Ti phase. As a result of solid-solution strengthening of $\alpha$ - Ti and massive transformation phase, the $\mathrm{Ti}-x \mathrm{Ag}$ showed better mechanical properties than the commercially pure titanium (cp-Ti). Electrochemical results showed that the $\mathrm{Ti}-x \mathrm{Ag}$ alloys exhibited improved corrosion resistance and oxidation resistance than $\mathrm{cp}-\mathrm{Ti}$.
\end{abstract}

Keywords: $\mathrm{Ti}-\mathrm{Ag}$ alloys; dental materials; corrosion resistance; mechanical properties; microstructure 


\section{Introduction}

Ti-based alloys have been widely used in fabrication of dental and orthopedic implants due to their favorable mechanical properties, including high strength-to-density ratio, good corrosion stability and high biocompatibility [1,2]. However, it is necessary to improve the mechanical properties of Ti for practical application in dentistry.

Recently, binary $\mathrm{Ti}-\mathrm{Ag}$ alloys have been developed for use in dental applications, due to their excellent corrosion resistance, improved mechanical properties and biocompatibility compared to commercially pure titanium (cp-Ti) [3-7]. In addition, the Ti-Ag alloys have a low ion-dissolution rate in $\mathrm{NaCl}$ solution [8]. Another study found that $\mathrm{Ag}$-coated $\mathrm{Ti}$ has an improved antibacterial effect, as well as good cell compatibility $[9,10]$. Due to the fact that intermetallic compounds, such as $\mathrm{Ti}_{2} \mathrm{Ag}$ and $\mathrm{TiAg}$, deteriorate the corrosion resistance of $\mathrm{Ti}$, the amount of $\mathrm{Ag}$ added to the Ti should be less than $25 \mathrm{wt} \%$ for use as dental materials [8]. The cytotoxicity tests performed by Zhang et al. show that $\mathrm{Ti}-\mathrm{Ag}$ alloys exhibited similar cell viability to that of $\mathrm{cp}-\mathrm{Ti}$ [11]. Other than this, there has been little experimental investigation about the relationship between phases/microstructure and the mechanical properties of $\mathrm{Ti}-\mathrm{Ag}$ alloys. Therefore, it is important to pursue a comprehensive structural analysis of $\mathrm{Ti}-\mathrm{Ag}$ alloys, which is necessary for developing new Ti-based alloys with desired properties.

Under certain conditions, several metallic alloys exhibit a composition-invariant transformation, which is termed massive transformation. Massive $\beta \rightarrow \alpha_{\mathrm{m}}$ transformation has been observed in $\mathrm{Ti}-x \mathrm{Ag}$ alloys containing $\mathrm{Ag} \leq 26 \mathrm{wt} \%$ [12]. In the present study, $\mathrm{Ti}-\mathrm{Ag}$ binary alloys with the addition of 5, 10,15 and $20 \mathrm{wt} \% \mathrm{Ag}$ were fabricated by arc melting. Massive transformation in the Ti-Ag alloys was observed using X-ray diffractometry (XRD), optical microscopy (OM), scanning electron microscopy (SEM) and transmission electron microscopy (TEM). In order to investigate the effects of massive transformation in $\mathrm{Ti}-\mathrm{Ag}$ alloys, the following analyses were carried out. Microhardness and elastic modulus were measured using a Vickers microhardness tester and a nanoindenter. Phase transformation and oxidation behavior were investigated by simultaneous differential scanning calometer (DSC) analysis and thermogravimetric analysis (TGA). Corrosion stability was evaluated through potentiodynamic polarization and galvanic corrosion tests in $0.9 \% \mathrm{NaCl}$ solution at $37 \pm 1{ }^{\circ} \mathrm{C}$. In this work, "Ti- $x \mathrm{Ag}$ " will henceforth stand for "Ti- $x$ wt $\% \mathrm{Ag}$ " in the text.

\section{Results and Discussion}

\subsection{Phase and Microstructure}

The X-ray diffraction patterns as a function of $x$ for the $\mathrm{Ti}-x \mathrm{Ag}(x=5,10,15$ and $20 \mathrm{wt} \%)$ samples are shown in Figure 1 and compared with the XRD pattern of cp-Ti. The patterns of Ti-xAg alloys could be indexed in the hexagonal $\alpha$-Ti type structure, the space group of $P 6_{3} / m m c$, with no indication of the existence of a secondary phase. This result was consistent with the previous analysis of phases in the Ti-Ag system $[13,14]$. With the exception of dilute $\mathrm{Ti}-5 \mathrm{Ag}$ and $\mathrm{Ti}-10 \mathrm{Ag}$ alloys, binary $\mathrm{Ti}-\mathrm{Ag}$ alloys commonly tend to precipitate intermetallic compounds $\mathrm{Ti}_{2} \mathrm{Ag}$ and $\mathrm{TiAg}$ when equilibrium solidification is considered. In light of this, at the eutectoid temperature, microstructure arrays constituted of the " $\alpha-\mathrm{Ti}+$ intermetallic $\mathrm{Ti}_{2} \mathrm{Ag}$ " phase form from the beta phase. In this study, however, 
owing to non-equilibrium solidification, no such intermetallic compounds were detected, in agreement with the results previously reported by Takahashi et al. [15].

Figure 1. X-ray diffractometry (XRD) patterns of the cast commercially pure titanium (cp-Ti) and the series of binary $\mathrm{Ti}-x \mathrm{Ag}(\mathrm{Ti}-x \mathrm{wt} \% \mathrm{Ag}$ ) alloys. (a) cp-Ti; (b) $\mathrm{Ti}-5 \mathrm{Ag}$; (c) $\mathrm{Ti}-10 \mathrm{Ag}$; (d) Ti-15Ag; and (e) Ti-20Ag.

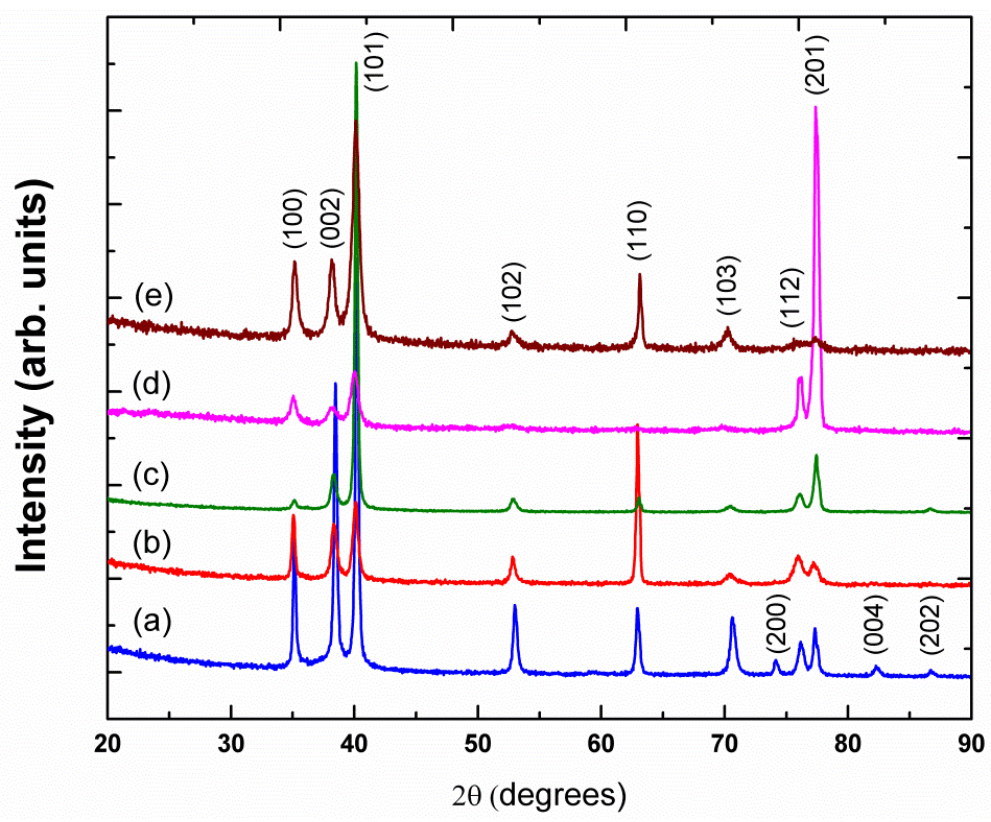

Rietveld refinements were performed in the present work to investigate the effect of $\mathrm{Ag}$ on the lattice parameters. The lattice parameter variations of $\mathrm{Ti}-x \mathrm{Ag}$ alloys as a function of $\mathrm{Ag}$ content are presented in Figure 2. Due to the similar atomic radius of $\operatorname{Ag}(\sim 1.44 \AA)$ and $\operatorname{Ti}(\sim 1.47 \AA)$, the alloying between $\mathrm{Ti}$ and $\mathrm{Ag}$ occurred as a solid solution. The addition of $\mathrm{Ag}$ atoms caused an increase in the lattice parameter $c$, whereas the lattice parameter $a$ remained constant. As a result, the $c / a$ ratio increased slightly as the content of Ag increased. Unit cell constants of cp-Ti were $a=2.951(1) \AA$ and $c=4.683(1) \AA(c / a$ ratio $=1.581)$, and they corresponded well with those in the literature (JCPDS card No. 44-1294), whereas the unit cell parameters of Ti-20Ag were $a=2.950(1) \AA$ and $c=4.721(1) \AA$ $(c / a$ ratio $=1.600)$. The trends of lattice parameters based on the Ag content were in agreement with the result obtained in a previous study [16].

Figure 2. (a,b) Lattice parameters $(a$ and $c)$ of cp-Ti and as-cast Ti- $x$ Ag alloys and (c) the variation in the ratio $(c / a)$ of lattice parameters.

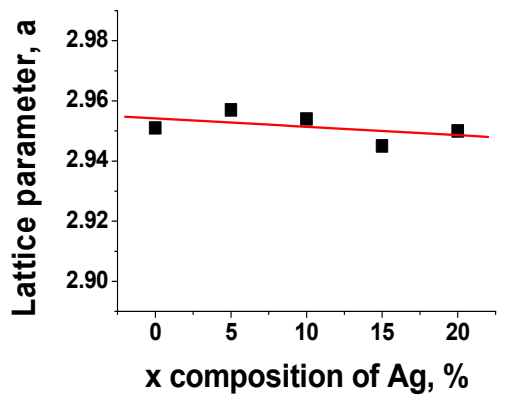

(a)

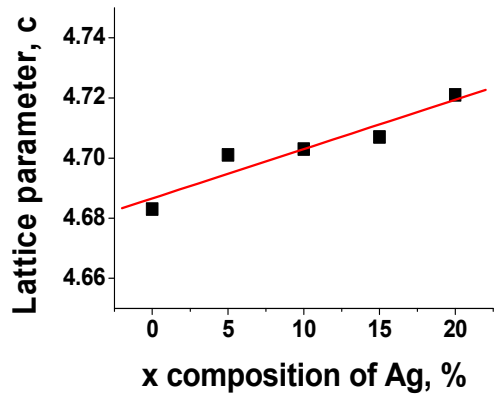

(b)

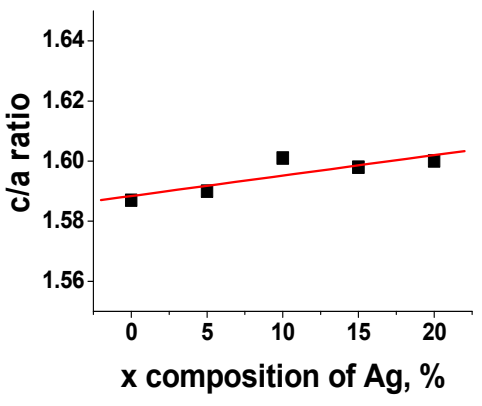

(c) 
Massive $\beta \rightarrow \alpha_{\mathrm{m}}$ transformation is known to occur in the Ti-xAg alloys containing $\mathrm{Ag} \leq 26 \mathrm{wt} \%$ [12]. The product phase has a different crystal structure from that of the matrix phase, but it has the same composition as the matrix phase. Therefore, massive transformation is composition invariant, but it shows an incoherent interface. Figures 3 and 4 show the OM and TEM images of Ti- $x$ Ag alloys with different $\mathrm{Ag}$ contents $(5,10,15$ and $20 \mathrm{wt} \%)$. In $\mathrm{Ti}-10 \mathrm{Ag}$, the grains of $\mathrm{Ti}-5 \mathrm{Ag}$ changed to an equiaxed structure with irregular grain boundaries, as shown in Figure 3a,b. Acicular structures were observed in $\mathrm{Ti}-\mathrm{Ag}$ alloys having Ag contents above $10 \mathrm{wt} \%$, and these structures became smaller with increasing Ag content, as shown in Figure 3c,d. The matrix was composed of the $\alpha$-Ti phase, as indicated by the selected area energy diffraction (SAED) pattern (inset in Figure 4).

Figure 3. Optical micrographs of Ti-xAg alloys; (a) Ti-5Ag; (b) $\mathrm{Ti}-10 \mathrm{Ag}$; (c) $\mathrm{Ti}-15 \mathrm{Ag}$; and (d) $\mathrm{Ti}-20 \mathrm{Ag}$.
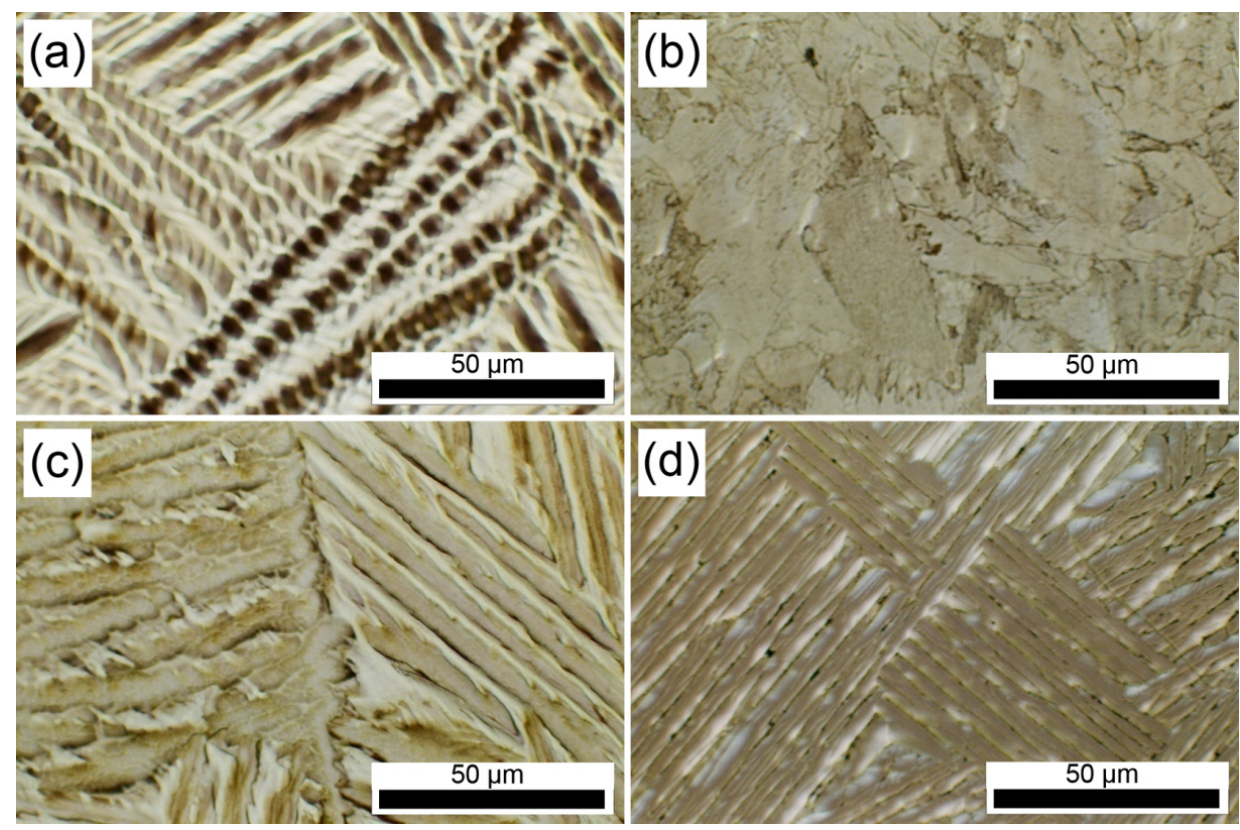

Figure 4. TEM micrographs of Ti-xAg alloys; (a) Ti-5Ag; (b) Ti-10Ag; (c) $\mathrm{Ti}-15 \mathrm{Ag}$; and (d) Ti-20Ag.
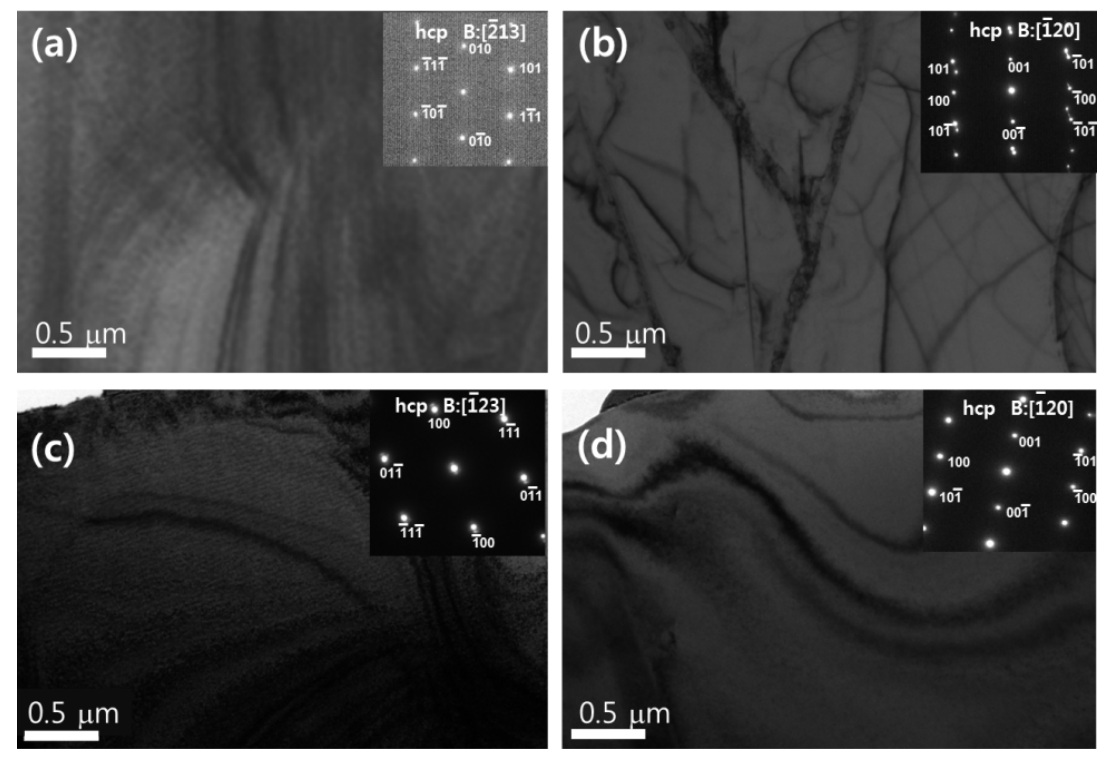
Confirmation of this massive transformation was provided by qualitative energy dispersive X-ray (EDX) analysis of Ti-10Ag alloys. SEM analysis of polished surfaces showed two different morphologies, which are marked as $\mathrm{A}$ and $\mathrm{B}$ in Figure 5a. The EDX analysis revealed that, within experimental limits, the composition of both morphologies was identical. Therefore, the observed transformation was composition invariant. Massive transformation was reconfirmed through observation of the microstructure using high-resolution transmission electron microscopy (HR-TEM). Figure $5 \mathrm{~b}$ shows the representative TEM image for the Ti-10Ag alloy. HR-TEM showed that the phase interface was incoherent. The SAED patterns of the Ti-10Ag alloy consisted of the characteristic hexagonal close packed (hcp) Ti phase of the matrix, showing perfect atomic arrangement and the sub-microstructure of the face centered cubic (fcc) Ti phase. The corresponding SAED patterns of the sub-microstructure could be indexed in terms of the [110] zone axis of the cubic structure of Ti.

Figure 5. (a) SEM micrograph with quantitative EDX analysis of $\mathrm{Ti}-10 \mathrm{Ag}$ alloy; and (b) HR-TEM micrograph with the SAED pattern of the Ti-10Ag alloy.

(a)

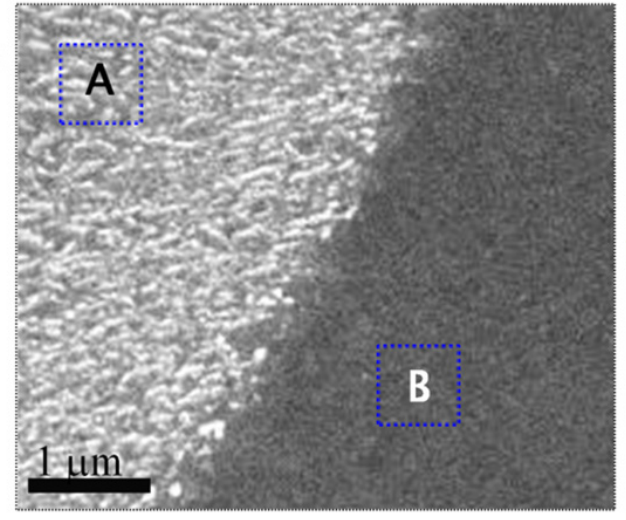

(b)

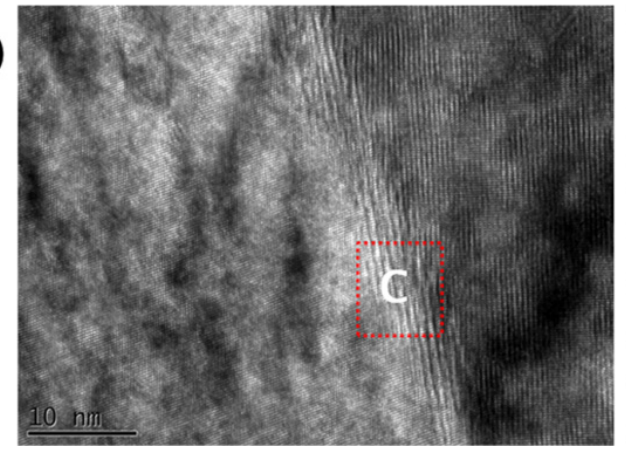

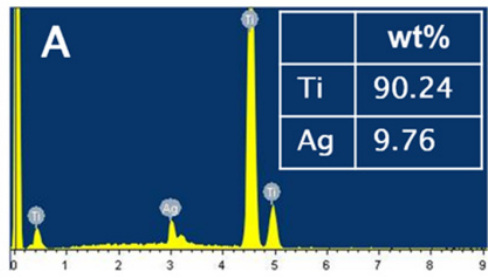
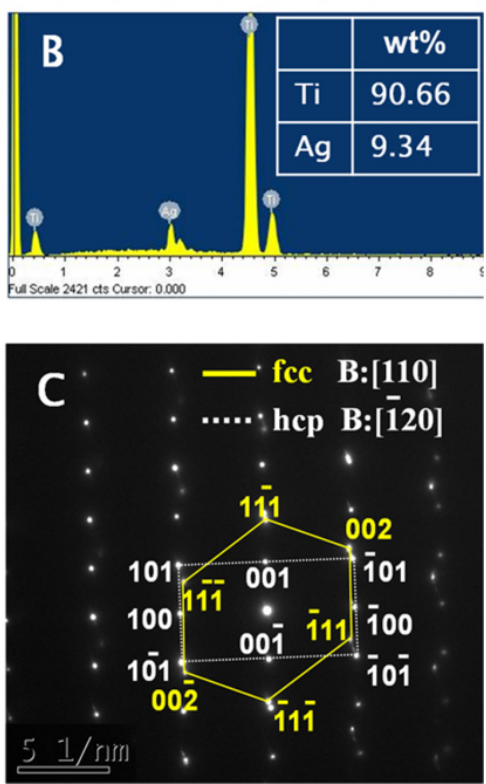

Differential scanning calorimetry (DSC) analysis was performed to detect any abnormal thermal effects from room temperature to $1000{ }^{\circ} \mathrm{C}$, which could be indicative of the presence of a free segregation of Ag or intermetallic precipitates. As shown in Figure 6, very smooth temperature-dependent traces were found at about $150{ }^{\circ} \mathrm{C}$ for all of the $\mathrm{Ti}-x \mathrm{Ag}$ alloys with $\mathrm{Ag}$ content up to $20 \mathrm{wt} \%$. This peak resulted from the stabilization of the thermally unstable structure, such as grain boundary relaxation or grain boundary reordering. The second endothermic peak at about $900{ }^{\circ} \mathrm{C}$ resulted from the martensitic transformation of $\alpha$-Ti to $\beta$-Ti. Other than these two peaks, no extraneous exothermic or endothermic peaks were detected. Thus, based on the XRD, SEM, TEM and DSC results, we could conclude that the nominal $20 \mathrm{wt} \%$ content of Ag used in this work did not exceed the solubility limit of Ag in the Ti alloys. 
Figure 6. Differential scanning calorimetry (DSC) curves of the cast cp-Ti and series of binary $\mathrm{Ti}-x \mathrm{Ag}$ alloys.

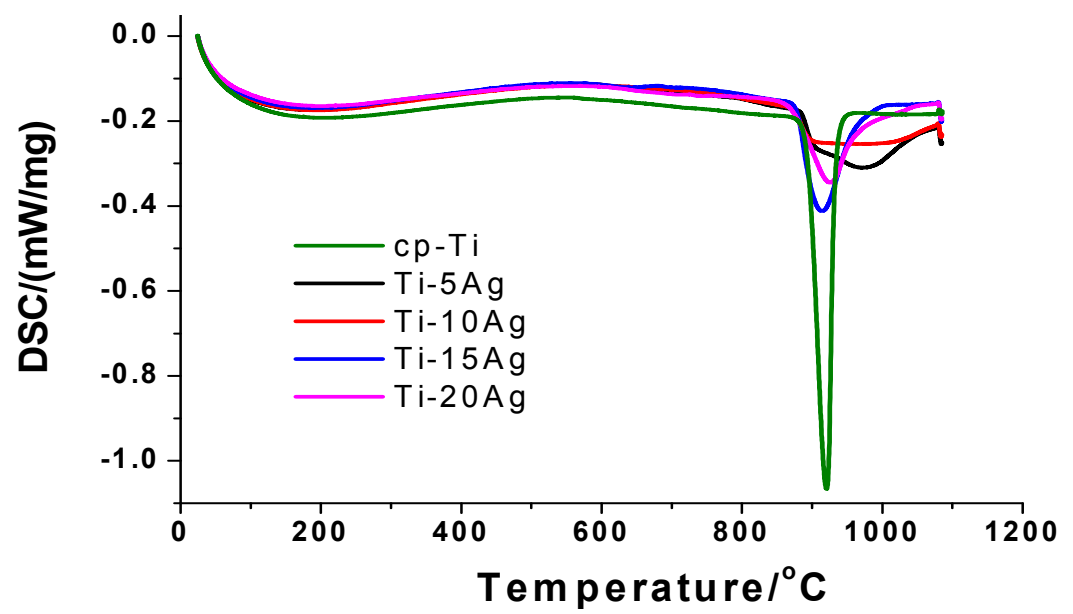

The oxidation behavior of $\mathrm{Ti}-x \mathrm{Ag}$ alloys was assessed using thermogravimetric analysis (TGA). Figure 7 shows the result of the TGA experiment when the cp-Ti and $\mathrm{Ti}-x \mathrm{Ag}$ alloys were heated up to $795{ }^{\circ} \mathrm{C}$ and $1000{ }^{\circ} \mathrm{C}$ at a heating rate of $10{ }^{\circ} \mathrm{C} / \mathrm{min}$ in air. Each sample was oxidized, and the weight gain in the oxidized samples was compared with the weight of the non-oxidized samples. All of the samples showed a single parabolic increment in mass during oxidation. The change in mass was not observed between room temperature to $600{ }^{\circ} \mathrm{C}$ in all of the $\mathrm{Ti}-x \mathrm{Ag}$ alloys, which was indicative of the oxidation resistance. At temperatures higher than $600{ }^{\circ} \mathrm{C}$, the mass of the Ti-xAg alloys increased exponentially. The weight change was increased with an increase in the oxidation temperature. The final mass change in the $\mathrm{Ti}-x \mathrm{Ag}$ alloys was significantly less than that in the $\mathrm{cp}$-Ti, indicating that the addition of $\mathrm{Ag}$ to $\mathrm{cp}$ - $\mathrm{Ti}$ could restrain the oxidation rate of the alloy, and $\mathrm{Ti}-x \mathrm{Ag}$ alloys had a high oxidation protection ability. The weight gain was decreased by increasing the $\mathrm{Ag}$ content up to $15 \mathrm{wt} \%$, and then, it was increased by increasing the Ag content further. Therefore, Ti- $x$ Ag alloys had a higher oxidation protection ability, and the addition of $\mathrm{Ag}$ to $\mathrm{cp}$-Ti could restrain the oxidation rate of the alloy.

Figure 7. Thermogravimetric analysis (TGA) of cp-Ti and $\mathrm{Ti}-x \mathrm{Ag}$ alloys showing various degrees of weight gain (\%) by heating in air up to $795^{\circ} \mathrm{C}$ and $1000{ }^{\circ} \mathrm{C}$.

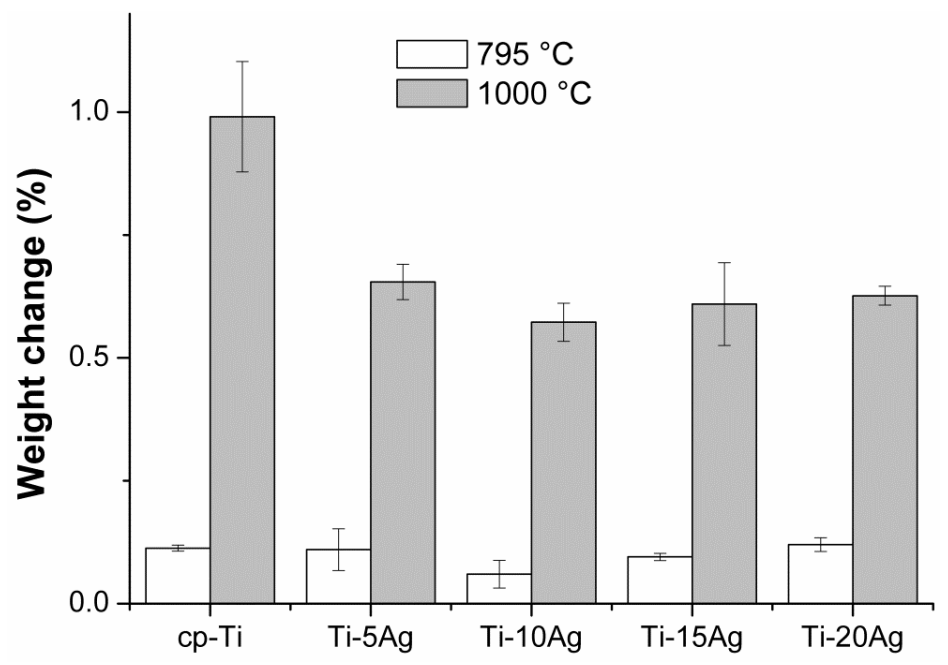




\subsection{Mechanical Properties}

The Vickers hardness means and elastic modulus of each $\mathrm{Ti}-x \mathrm{Ag}$ alloy are shown in Table 1, and these values are compared to those of $\mathrm{cp}$ - Ti. The Ag element could effectively increase the microhardness values of cp-Ti (165 Vickers Hardness (VHN)), which could be explained by solid-solution strengthening of the $\alpha$-phase, as suggested in a previous study $[17,18]$. Among the $\mathrm{Ti}-x \mathrm{Ag}$ alloys, $\mathrm{Ti}-10 \mathrm{Ag}$ exhibited the highest hardness value of $501 \mathrm{VHN}$. This increase in hardness was probably caused by the massive transformation of the $\alpha$ phases along with solid-solution strengthening. The elastic modulus of $\mathrm{cp}$-Ti was $132 \mathrm{GPa}$. The elastic modulus of $\mathrm{Ti}-5 \mathrm{Ag}$ was slightly higher than that of cp-Ti, whereas the elastic moduli of the other Ti-xAg alloys $(x=10,15$ and 20) were lower $(p<0.05)$ than that of the cp-Ti. The lowering of the elastic modulus by alloying Ti with Ag atoms was attributed to the imperfect $\alpha$ phases during massive transformation [13]. The elastic modulus values for the $\mathrm{Ti}-x \operatorname{Ag}(x=10,15$ and $20 \mathrm{wt} \%)$ alloys were in the range of $122-130 \mathrm{GPa}$, which is comparable to the previously reported values [19].

Table 1. Vickers hardness and elastic modulus values of Ti- $x$ Ag alloys compared to cp-Ti $(n=5)$.

\begin{tabular}{ccc}
\hline Alloy Code & Vickers Hardness (VHN) & Elastic Modulus (GPa) \\
\hline $\mathrm{cp}-\mathrm{Ti}$ & $165.0(2.6)^{\mathrm{a}, *}$ & $132.4(12.2)^{\mathrm{b}, \mathrm{c}, *}$ \\
$\mathrm{Ti}-5 \mathrm{Ag}$ & $251.7(1.2)^{\mathrm{b}}$ & $140.4(4.9)^{\mathrm{c}}$ \\
$\mathrm{Ti}-10 \mathrm{Ag}$ & $501.0(17.3)^{\mathrm{c}}$ & $126.4(8.5)^{\mathrm{a}, \mathrm{b}}$ \\
$\mathrm{Ti}-15 \mathrm{Ag}$ & $275.3(11.0)^{\mathrm{b}}$ & $129.6(7.0)^{\mathrm{a}, \mathrm{b}}$ \\
$\mathrm{Ti}-20 \mathrm{Ag}$ & $485.0(68.4)^{\mathrm{c}}$ & $122.7(4.6)^{\mathrm{a}}$ \\
\hline
\end{tabular}

* Within the same column, mean values with the same superscript letter were not statistically different at $5 \%$ $(p>0.05)$ by the Duncan's multiple range test.

\subsection{Corrosion Behavior}

Potentiodynamic polarization and the galvanic couple technique were used to investigate the effect of $\mathrm{Ag}$ content on corrosion resistance. The potentiodynamic polarization curves of the $\mathrm{cp}-\mathrm{Ti}$ and $\mathrm{Ti}-x \mathrm{Ag}$ alloys were recorded at a sweep rate of $5 \mathrm{mV} / \mathrm{s}$ in the potential range of -1.5 to $1.5 \mathrm{~V}$ in deaerated $0.9 \% \mathrm{NaCl}$ solution $(\mathrm{pH}=7.02)$, and the results are shown in Figure $8 \mathrm{a}$. The initial passive potential of $\mathrm{Ti}-x \mathrm{Ag}$ alloys showed a shift in the positive direction as compared to that of cp-Ti, which indicated a remarkable enhancement in the corrosion resistance by $\mathrm{Ag}$ addition. The initial passive current densities $\left(\sim 12.8 \mu \mathrm{A} / \mathrm{cm}^{2}\right)$ of Ti-10Ag and Ti-15Ag were observed to be smaller than that $\left(21.70 \mu \mathrm{A} / \mathrm{cm}^{2}\right)$ of cp-Ti. The increase in the initial passive current density was observed for Ti-5Ag $\left(21.28 \mu \mathrm{A} / \mathrm{cm}^{2}\right)$ and Ti-20Ag $\left(25.83 \mu \mathrm{A} / \mathrm{cm}^{2}\right)$. Figures $8 \mathrm{~b}-\mathrm{f}$ show the Tafel plots obtained from the representative potentiodynamic polarization curves of the cp-Ti and Ti-xAg alloys (Figure 8a). 
Figure 8. Representative potentiodynamic polarization curves for the $\mathrm{cp}-\mathrm{Ti}$ and $\mathrm{Ti}-x \mathrm{Ag}$ alloys. SCE, saturated calomel electrode.

(a)

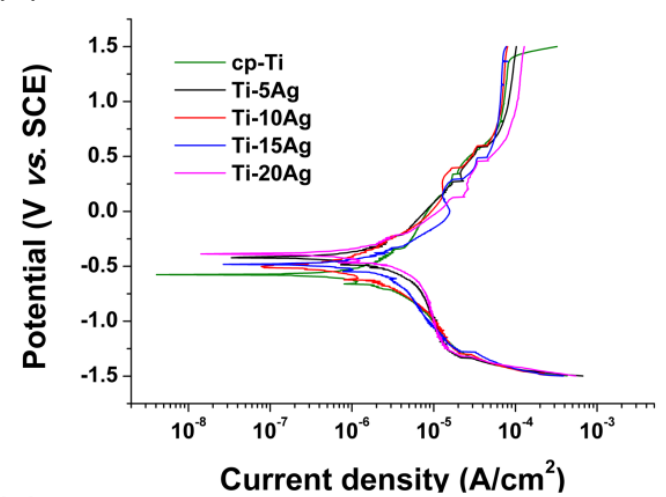

(c)

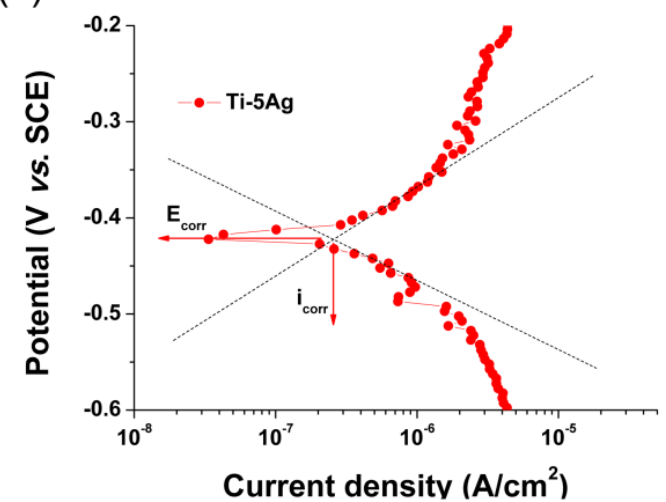

(e)

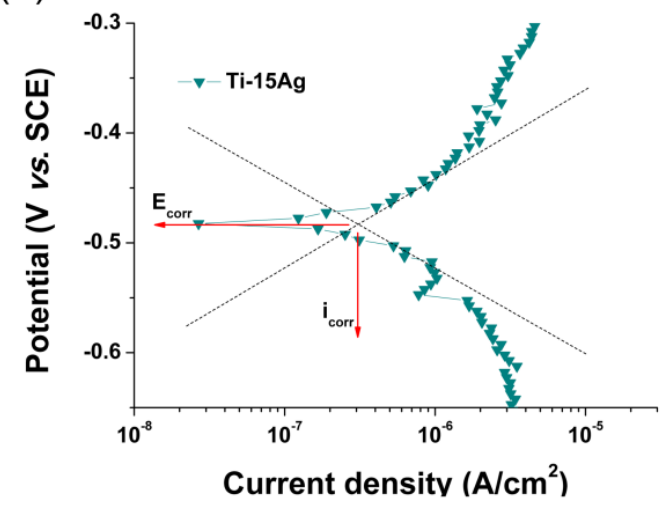

(b)

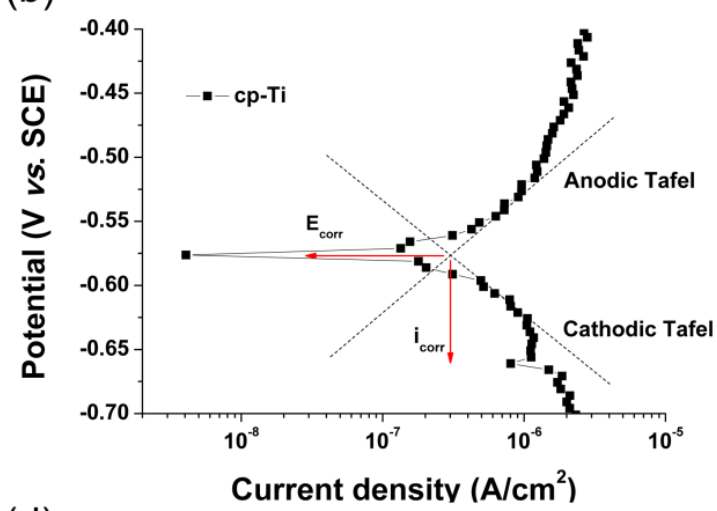

(d)

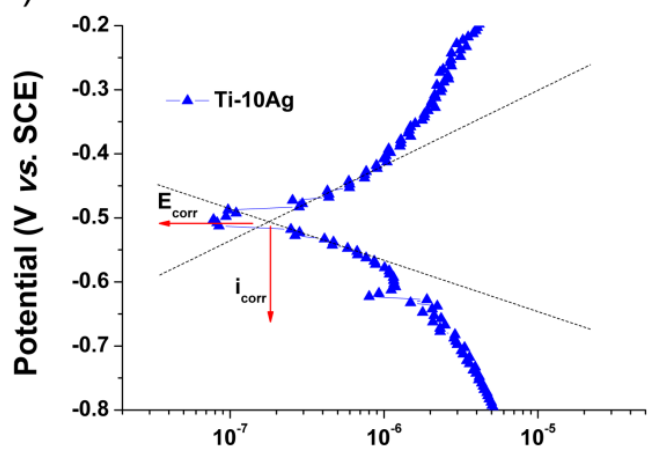

Current density $\left(\mathrm{A} / \mathrm{cm}^{2}\right)$

(f)

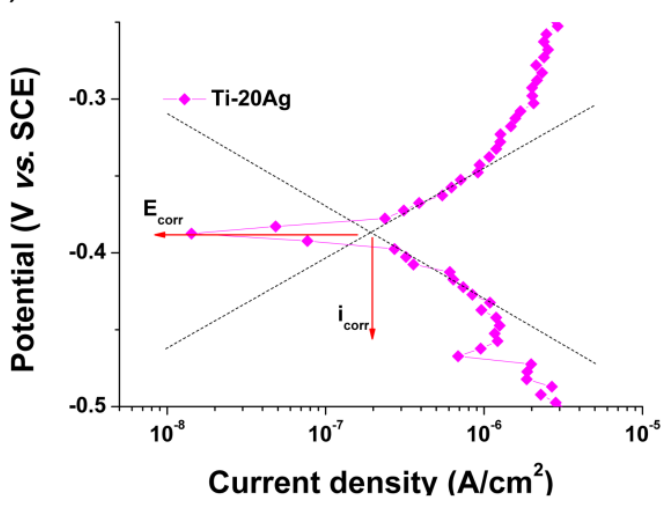

Using the Tafel extrapolation method, we calculated the corrosion potential $\left(E_{\text {corr }}\right)$ and corrosion current density $\left(i_{\text {corr }}\right)$ of $\mathrm{cp}-\mathrm{Ti}$ and $\mathrm{Ti}-x \mathrm{Ag}$ alloys using both anodic and cathodic branches of the potentiodynamic polarization curves, and they are listed in Table 2 . The average corrosion potential and current density values of all of the investigated $\mathrm{Ti}-x \mathrm{Ag}$ alloys were respectively higher and lower than those of cp-Ti. Although no statistically significant difference was observed in the $i_{\text {corr }}$ values among the tested cp-Ti and $\mathrm{Ti}-x \mathrm{Ag}$ alloy samples, $\mathrm{Ti}-10 \mathrm{Ag}$ showed a slightly higher $i_{\text {corr }}$ value. It is presumed that the decreased $E_{\text {corr }}$ and increased $i_{\text {corr }}$ values of $\mathrm{Ti}-10 \mathrm{Ag}$ can be attributed to the irregular boundaries of its equiaxed grains. With the exception of $\mathrm{Ti}-10 \mathrm{Ag}$, the $E_{\text {corr }}$ values for all alloys increased with increasing silver content, with microstructural changes to acicular forms and smaller phases. These results demonstrated that alloying Ti with Ag increased the corrosion resistance, which was probably caused by the accumulation of noble Ag atoms on the surface of Ti-Ag alloys due 
to the loss of Ti during the corrosion process [4,20]. Zhang et al. [11] reported that $\mathrm{Ti}-10 \mathrm{Ag}$ has a corrosion resistance expressed as a function of electrochemical impedance behavior lower than those of both $\mathrm{Ti}-5 \mathrm{Ag}$ and $\mathrm{Ti}-20 \mathrm{Ag}$ alloys. It seems that the eutectoid reaction is intimately associated with the decrease in the corrosion resistance of $\mathrm{Ti}-10 \mathrm{Ag}$ compared with the other two examined $\mathrm{Ti}-\mathrm{Ag}$ alloys. It is well-known that the microstructure array resulting from the eutectoid reaction plays an important role in determining the electrochemical behavior, as previously reported for a number of as-cast Ti-based alloys [21,22] and various other non-ferrous alloys [23,24].

Table 2. Corrosion potential $\left(E_{\text {corr }}\right)$ and corrosion current density $\left(i_{\text {corr }}\right)$ of $\mathrm{cp}$-Ti and $\mathrm{Ti}-x \mathrm{Ag}$ alloys $(n=3)$.

\begin{tabular}{ccc}
\hline Alloy Code & $\boldsymbol{E}_{\text {corr }}(\mathbf{m V})$ & $\boldsymbol{i}_{\text {corr }}\left(\boldsymbol{\mu} \mathbf{A} / \mathbf{c m}^{\mathbf{2}}\right)$ \\
\hline cp-Ti & $-550.33(43.94)^{\mathrm{a}, *}$ & $0.287(0.046)^{\mathrm{a}, *}$ \\
Ti-5Ag & $-471.07(101.37)^{\mathrm{a}, \mathrm{b}}$ & $0.209(0.072)^{\mathrm{a}}$ \\
Ti-10Ag & $-500.20(31.82)^{\mathrm{a}, \mathrm{b}}$ & $0.231(0.057)^{\mathrm{a}}$ \\
Ti-15Ag & $-461.33(19.98)^{\mathrm{a}, \mathrm{b}}$ & $0.181(0.120)^{\mathrm{a}}$ \\
Ti-20Ag & $-416.98(58.72)^{\mathrm{b}}$ & $0.221(0.078)^{\mathrm{a}}$ \\
\hline
\end{tabular}

* Within the same column, mean values with the same superscript letter were not statistically different at $5 \%$ $(p>0.05)$ by the Duncan's multiple range test.

Mean values of galvanic currents versus time of the couplings of cp- $\mathrm{Ti} / \mathrm{Ti}-x \mathrm{Ag}$ alloys are shown in Figure 9. All of the $\mathrm{Ti}-x \mathrm{Ag}$ alloys apparently behaved in a similar manner. Current values initially exhibited a rapid increase and then leveled off. This general behavior might be explained by the reduction in the active area due to the growth of a passive film on the surface of cp-Ti. A steady-state current value was attained more rapidly for $\mathrm{Ti}-5 \mathrm{Ag}$ and $\mathrm{Ti}-10 \mathrm{Ag}$ compared to $\mathrm{cp}-\mathrm{Ti}$, indicating that the passive film grew more rapidly on $\mathrm{cp}-\mathrm{Ti}$. The time required for the $\mathrm{Ti}-x \mathrm{Ag}$ alloys to attain a constant current was increased as the amount of $\mathrm{Ag}$ increased.

Figure 9. Mean values of galvanic currents $v s$. time of the couplings of $\mathrm{cp}-\mathrm{Ti} / \mathrm{Ti}-x \mathrm{Ag}$ alloys.

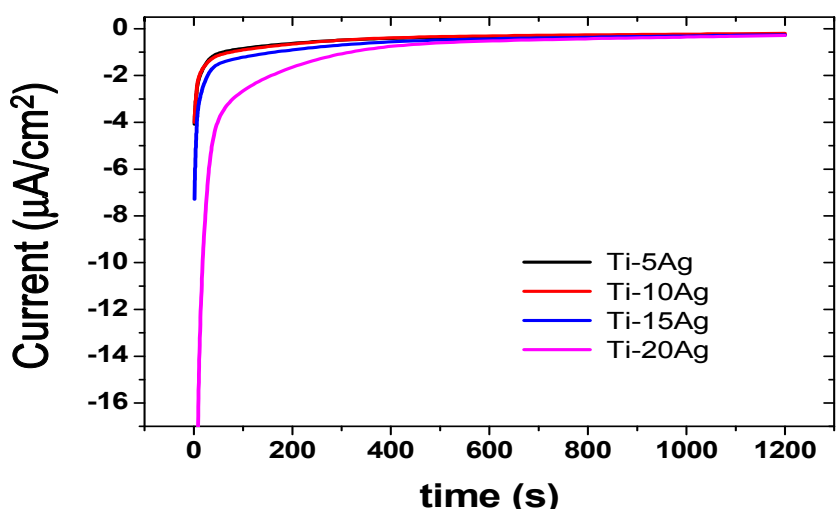

\section{Experimental Section}

\subsection{Material Preparation}

A commercially-available cp-Ti (ASTM Grade II, Daito Steel Co. Ltd., Tokyo, Japan) was used as the control titanium material. Experimental Ti-Ag alloys (5, 10, 15 and 20 mass\% Ag) were prepared by 
arc-melting the stoichiometric quantities of the elements on a water-cooled copper hearth using a tungsten electrode under a high-purity argon atmosphere. The starting materials (Ti sponge, Alfa Aesar, Ward Hill, MA, USA, 99.9\%; Ag ingot, LS-Nikko, Seoul, Korea, 99.95\%) were used without purification. During the arc-melting procedure, a titanium getter was heated prior to melting the reactant mixture to further purify the argon atmosphere. The samples were remelted seven times to promote sample homogeneity. Subsequently, the samples were heat treated using a tube furnace under argon atmosphere for $4 \mathrm{~h}$ at temperatures $150{ }^{\circ} \mathrm{C}$ below the respective solidus temperatures followed by cooling down to $600{ }^{\circ} \mathrm{C}$ in a furnace at a rate of $10{ }^{\circ} \mathrm{C} / \mathrm{min}$ and air-cooling to room temperature. These heat treatment conditions were chosen in accordance with the binary $\mathrm{Ti}-\mathrm{Ag}$ phase diagrams [16].

\subsection{Material Characterization}

Phase analysis and structural characterization were performed by X-ray diffraction (XRD). The XRD diffraction patterns were collected for the bulk sample using a X'Pert PRO Multi-Purpose X-Ray Diffractometer (40 kV and $40 \mathrm{~mA}$, PANalytical B.V., Almelo, The Netherlands) with $\mathrm{Cu} \mathrm{K}_{\alpha}$ $(\lambda=1.54056 \AA)$. Intensities of the XRD were obtained in the $2 \theta$ range between $20^{\circ}$ and $90^{\circ}$ with a step size of $0.02^{\circ} / 3 \mathrm{~s}$. The lattice parameters were obtained by least squares refinement of data in the $2 \theta$ range of $20^{\circ}-90^{\circ}$ with the aid of a Rietveld refinement program [25]. The microstructure of samples was examined using optical/metallurgical microscopy (Epiphot FX-35WA, Nikon, Tokyo, Japan), scanning electron microscopy (SEM; Hitachi, S-3000N, Tokyo, Japan.), high-resolution transmission electron microscopy (HR-TEM; Philips, Technai-F20, Amsterdam, The Netherlands), selected area energy diffraction (SAED) and energy dispersive X-ray analysis (EDX; EMAX, Horiba, Kyoto, Japan). Compositions of the cast $\mathrm{Ti}-x \mathrm{Ag}$ alloys were determined using a scanning electron microscopy/energy dispersive spectrometry (SEM/EDS). Data collection was performed with a $20-\mathrm{kV}$ accelerating voltage and $15 \%$ of mean dead time. The acquisition rate was $6 \mathrm{kcps}$, and the magnification was $\times 200$. To carry out the quantitative analyses, pure $\mathrm{Ag}(99.95 \%)$ and $\mathrm{Ti}(99.99 \%)$ elements were used as standards (Taylor standard block, C60-001, CM Taylor Company, Amelia, VA, USA).

The phase transformation in $\mathrm{Ti}-x \mathrm{Ag}$ alloys was investigated by heating approximately $200 \mathrm{mg}$ of the sample to $1000{ }^{\circ} \mathrm{C}$ at a heating rate of $20{ }^{\circ} \mathrm{C} / \mathrm{min}$ using a differential scanning calorimeter (DSC, DSC 404 C, Netzsch, Selb, Germany). The oxidation behavior of cp-Ti with different Ag contents was tested with TGA (SDTA 851e, Mettler-Toledo, Columbus, OH, USA), which measures the change in mass due to oxidation. The samples measuring $4.5 \mathrm{~mm} \times 4.2 \mathrm{~mm} \times 14.0 \mathrm{~mm}$ in size were heated to $795{ }^{\circ} \mathrm{C}$ or $1000{ }^{\circ} \mathrm{C}$ at a heating rate of $10^{\circ} \mathrm{C} / \mathrm{min}$ with an air flowing rate of $50 \mathrm{~mL} / \mathrm{min}$. Duplicate samples were tested per each test group.

\subsection{Measurement of Mechanical Properties}

For the measurement of mechanical properties, samples embedded in epoxy resin were cut and polished into disks of about a 1.2-mm thickness with successively finer SiC papers up to \#2000 grit and then ultrasonically cleansed in distilled water. Subsequently, the polished samples were etched with Keller's solution (distilled water: 65\%; $\mathrm{HNO}_{3}$ : 32\%; $\mathrm{HCl}: 40 \%$; $\mathrm{HF}=$ 95:2.5:1.5:0.5). The microhardness of polished alloys was measured using a Vickers microhardness tester (Zwick, Postfach4350, Ulm, Germany) with a load of $500 \mathrm{~g}$ for $30 \mathrm{~s}$. Elastic modulus measurement 
was performed using Nanoindenter (MTS Company, Dubuque, IA, USA) in a continuous stiffness measurement mode with the Berkovich-type indenter. The indentations were made using a constant nominal strain rate of $5 \times 10^{-2} \mathrm{~s}^{-1}$. The maximum indentation depth was $2 \mu \mathrm{m}$. A Poisson's ratio of 0.35 was used to calculate the elastic modulus.

\subsection{Electrochemical Analysis}

The potentiodynamic anodic polarization test was conducted at a scan rate of $5 \mathrm{mV} / \mathrm{s}$ from -1.5 to $+1.5 \mathrm{~V}$ (vs. SCE (saturated calomel electrode)) using a potentiostat (WAT 100, WonA Tech Co., Ltd., Seoul, Korea) in $0.9 \% \mathrm{NaCl}$ solution at $37 \pm 1{ }^{\circ} \mathrm{C}$. At least three samples were tested to confirm the repetition of the experimental results. The surface of the sample with an approximately $10-\mathrm{mm}$ diameter was mechanically polished with $\mathrm{SiC}$ paper up to 2000 grit. The electrochemical measurements were recorded using the three electrode technique consisting of the working electrode (test samples), the counter electrode (high density carbon) and the reference electrode (saturated calomel electrode). Before measurements, argon gas was bubbled through the electrolyte at $150 \mathrm{~mL} / \mathrm{min}$ for more than $20 \mathrm{~min}$ to eliminate the residual oxygen in the electrolyte. Fresh electrolyte was used for each measurement. The exposed surface area of samples in the electrolyte was $0.283 \mathrm{~cm}^{2}$. Potentiodynamic anodic polarization measurements were carried out after an immersion period of $1 \mathrm{~h}$ at open circuit potential. The potentiodynamic polarization curves were plotted using an automatic data acquisition system. Corrosion potential and current density were estimated by the Tafel plots using both anodic and cathodic branches. The galvanic current densities of various $\mathrm{Ti}-x \mathrm{Ag} / \mathrm{cp}-\mathrm{Ti}$ galvanic pairs were measured over a 20 -min period by using a potentiostat/galvanostat at ambient conditions (ZIVE SP2, WonA Tech Co., Ltd., Seoul, Korea). The experimental setup for electrochemical measurements consisted of a three-electrode cell with the sample as a working electrode with an exposed area of $0.785 \mathrm{~cm}^{2}$, a saturated calomel electrode (SCE) as a reference electrode and cp-Ti as the counter electrode.

\subsection{Statistical Analysis}

Version 19.0 of the statistical software, SPSS (SPSS, Inc., Chicago, IL, USA), was used to analyze the data by means of the Kruskal-Wallis one-way analysis of variance and Duncan's multiple range test with $\alpha=0.05$. Data were expressed as the mean \pm standard deviation (SD) for each of the tests.

\section{Conclusions}

This study investigated the influence of $\mathrm{Ag}$ addition on the microstructure, mechanical properties and corrosion behavior of commercially pure titanium (cp-Ti). The Ti-xAg alloys exhibited $\alpha-\mathrm{Ti}$ structure at a silver content below $20 \mathrm{wt} \%$. Based on the EDX and HR-TEM analysis, all of the Ti- $x \mathrm{Ag}$ alloys showed a massive transformation from the $\beta$-Ti to $\alpha_{\mathrm{m}}$ phase, which has a different crystal structure from that of the matrix phase, but it has the same composition as the matrix $\alpha$-Ti phase. As a result of solid-solution strengthening of $\alpha$-Ti and massive transformation phase, the Ti-xAg exhibited higher hardness and better oxidation protection ability than the cp-Ti. Electrochemical results showed that the $\mathrm{Ti}-x \mathrm{Ag}$ alloys exhibited improved corrosion resistance compared to cp-Ti. After considering 
the mechanical properties and corrosion behavior of $\mathrm{Ti}-x \mathrm{Ag}$ alloys, $\mathrm{Ti}$ alloys with $\mathrm{Ag}$ addition can be considered as good candidates for dental casting alloys.

\section{Acknowledgments}

This research was supported by the National Research Foundation of Korea (NRF) grant funded by the Korea government (MSIP) (No. 2011-00301212) and by the Basic Science Research Program through the NRF funded by the Ministry of Education, Science and Technology (2011-0002706).

\section{Author Contributions}

The massive transformation of $\mathrm{Ti}-x \mathrm{Ag}$ alloys was investigated by Mi-Kyung Han. The electrochemical (Tafel plot) data was calculated by Moon-Jin Hwang. The technical knowledge for alloy design was provided by Dae-Hee Won and Yang-Soo Kim. The analysis of TEM images was performed by Ho-Jun Song. The research work outlined in this paper was designed and supervised by Yeong-Joon Park.

\section{Conflicts of Interest}

The authors declare no conflict of interest.

\section{References}

1. Leyens, C.; Peters, M. Titatium and Titanium Alloys: Fundamentals \& Applications; WILEY-VCH Verlag GmbH \& Co. KGaA: Weinheim, Germany, 2003; pp. 423-466.

2. Lloyd, C.H.; Scrimgeour, S.N.; Brown, D.; Clarke, R.L.; Curtis, R.V.; Hatton, P.V. Dental materials: 1995 literature review. J. Dent. 1997, 25, 173-208.

3. Wang, Q.Y.; Wang, Y.B.; Lin, J.P.; Zheng, Y.F. Development and properties of Ti-In binary alloys as dental biomaterials. Mater. Sci. Eng. C 2012, 33, 1601-1606.

4. Shim, H.M.; Oh, K.T.; Woo, J.Y.; Hwang, C.J.; Kim, K.N. Corrosion resistance of titanium-silver alloys in an artificial saliva containing fluoride ions. J. Biomed. Mater. Res. Part B Appl. Biomater. 2005, 73, 252-259.

5. Zhang, B.; Wang, B.; Li, L.; Zheng, Y. Corrosion behavior of Ti-5Ag alloy with and without thermal oxidation in artificial saliva solution. Dental Mater. 2011, 27, 214-220.

6. Takahashi, M.; Kikuchi, M.; Takada, Y.; Okuno, O. In grindability and mechanical properties of experimental Ti-Au, Ti-Ag and Ti-Cu alloys. Int. Congr. Ser. 2005, 1284, 326-327.

7. Kikuchi, M.; Takahashi, M.; Okabe, T.; Okuno, O. Grindability of dental cast Ti-Ag and Ti-Cu alloys. Dental Mater. J. 2003, 22, 191-205.

8. Takahashi, M.; Kikuchi, M.; Takada, Y.; Okuno, O. Corrosion resistance of dental Ti-Ag alloys in $\mathrm{NaCl}$ solution. Mater. Trans. 2010, 51, 762-766.

9. Song, D.-H.; Uhm, S.-H.; Lee, S.-B.; Han, J.-G.; Kim, K.-N. Antimicrobial silver-containing titanium oxide nanocomposite coatings by a reactive magnetron sputtering. Thin Solid Films 2011, 519, 7079-7085. 
10. Kang, M.-K.; Moon, S.-K.; Kwon, J.-S.; Kim, K.-M.; Kim, K.-N. Antibacterial effect of sand blasted, large-grit, acid-etched treated Ti-Ag alloys. Mater. Res. Bull. 2012, 47, 2952-2955.

11. Zhang, B.; Qiu, K.; Wang, B.; Li, L.; Zheng, Y. Surface characterization and cell response of binary Ti-Ag alloys with cp-Ti as material control. J. Mater. Sci. Technol. 2012, 28, 779-784.

12. Plichta, M.; Williams, J.; Aaronson, H. On the existence of the $\beta \rightarrow \alpha_{\mathrm{m}}$ transformation in the alloy systems Ti-Ag, Ti-Au, and Ti-Si. Metall. Trans. A 1977, 8, 1885-1892.

13. Kikuchi, M.; Takahashi, M.; Sato, H.; Okuno, O.; Nunn, M.E.; Okabe, T. Grindability of cast Ti-Hf alloys. J. Biomed. Mater. Res. B Appl. Biomater. 2006, 77, 34-38.

14. Takada, Y.; Takahashi, M.; Kikuchi, M. The development of binary titanium alloys with the aim of dental applications. In Interface Oral Health Science 2011; Springer: Berlin, Germany, 2012; pp. 66-71.

15. Takahashi, M.; Kikuchi, M.; Takada, Y.; Okabe, T.; Okuno, O. Electrochemical behavior of cast Ti-Ag alloys. Dental Mater. J. 2006, 25, 516-523.

16. Murray, J.L. Phase Diagrams of Binary Titanium Alloys; American Society for Metals (ASM): Geauga County, OH, USA, 1987; pp. 6-11.

17. Oh, K.T.; Shim, H.M.; Kim, K.N. Properties of titanium-silver alloys for dental application. J. Biomed. Mater. Res. B Appl. Biomater. 2005, 74, 649-658.

18. Takahashi, M.; Kikuchi, M.; Hatori, K.; Orii, Y.; Sasaki, K.; Takada, Y. Calcium phosphate formation on Ti-Ag alloys in simulated body fluid. J. Biomech. Sci. Eng. 2009, 4, 318-325.

19. Yoda, M.; Konno, T.; Takada, Y.; Iijima, K.; Griggs, J.; Okuno, O.; Kimura, K.; Okabe, T. Bond strength of binary titanium alloys to porcelain. Biomaterials 2001, 22, 1675-1681.

20. Zhang, B.; Zheng, Y.; Liu, Y. Effect of Ag on the corrosion behavior of Ti-Ag alloys in artificial saliva solutions. Dental Mater. 2009, 25, 672-677.

21. Martins, D.Q.; Osorio, W.R.; Souza, M.E.P.; Caram, R.; Garcia, A. Effects of Zr content on microstructure and corrosion resistance of $\mathrm{Ti}-30 \mathrm{Nb}-\mathrm{Zr}$ casting alloys for biomedical applications. Electrochim. Acta 2008, 53, 2809-2817.

22. Osório, W.R.; Cremasco, A.; Andrade, P.N.; Garcia, A.; Caram, R. Electrochemical behavior of centrifuged cast and heat treated $\mathrm{Ti}-\mathrm{Cu}$ alloys for medical applications. Electrochim. Acta 2010, $55,759-770$.

23. Osorio, W.R.; Cheung, N.; Spinelli, J.E.; Garcia, A. The effects of a eutectic modifier on microstructure and surface corrosion behavior of Al-Si hypoeutectic alloys. J. Solid State Electrochem. 2007, 11, 1421-1427.

24. Peixoto, L.C.; Osorio, W.R.; Garcia, A. Microstructure and electrochemical corrosion behavior of a $\mathrm{Pb}-1 \mathrm{wt} \%$ Sn alloy for lead-acid battery components. J. Power Sources 2009, 192, 724-729.

25. Hunter, B.A.; Howard, C.J. Rietica; Australian Nuclear Science and Technology Organization: Menai, Australia, 2000.

(C) 2014 by the authors; licensee MDPI, Basel, Switzerland. This article is an open access article distributed under the terms and conditions of the Creative Commons Attribution license (http://creativecommons.org/licenses/by/3.0/). 